\title{
EU Policies for Refugee Protection and Immigration: Cooperation is Key
}

On 13 July 2018, the UN agreed on the final draft of the Global Compact for Safe, Orderly, and Regular Migration. In essence, the Compact summarises the good intentions of governments and describes good practices in migration governance. Above all, the Compact asserts that "no State can address migration on its own due to the inherently transnational nature of the phenomenon". It also emphasises "an overarching obligation to respect, protect and fulfil the human rights of all migrants, regardless of their migration status".

EU heads of state and government, who will sign the Compact in December, may want to take time to read it carefully. Arguably, several of their conclusions from the June 2018 European Council, such as "regional disembarkation platforms" in third countries or "closed centres" in EU member states for newly arrived asylum seekers run counter to the spirit of the Compact. Furthermore, unilateral measures by some member states, such as Italy's temporary closing of its ports to potential asylum seekers, are perhaps a useful reminder to other member states that the Dublin system is no longer functioning. However, "cooperation and dialogue" among EU member states will be needed to design and implement a workable reform of the Dublin system that must involve, above all, more responsibility-sharing by member states for the EU asylum system.

The contrast between the common sense messages and humanitarian aspirations of the Compact on the one hand, and certain influential proposals for EU asylum policy on the other, points to a deeper problem with the EU asylum system. When most EU member states implemented the Schengen area and abolished identity checks at their internal EU borders, they failed to put a unified asylum system in place. Successive Dublin regulations essentially pretended that the Schengen process never happened and allocated responsibility for all asylum-related tasks to the EU member state where an asylum seeker first arrives. Moreover, EU member states of first arrival typically have an external EU (and Schengen area) border to secure and protect.

Most observers acknowledge that it is unfair - as well as unworkable - to place this entire burden on the EU member states of first arrival. The countries of first arrival in Southern Europe have every incentive not to register asylum seekers but rather to let them move on to Northern Europe, the preferred destination of many asylum seekers. This has occurred to such a large extent that Italy, despite being a prominent point of irregular entry into the $\mathrm{EU}$, hosts far fewer recognised refugees than it ought to based on any plausible distribution formula. Unsurprisingly, in Schengen states without a southern external border, such as Germany, there has been resistance to the inflow of asylum seekers who ought to have been registered (but were not) by other member states.

The current proposals by the European Commission for Dublin reform do not fully address these challenges. During the first half of 2018, the Bulgarian EU Presidency moved discussions forward on seven draft legal texts which, together, were meant to constitute a comprehensive overhaul of the Dublin system. However, member states made little progress on the key issue of when (and how many) refugees would be relocated from the country of first arrival to other member states. The current Austrian EU Presidency is unlikely to expend much energy advancing these texts. Rather, it may seek to make it altogether impossible to apply for asylum on EU territory - presumably, by transferring asylum seekers to locations outside the EU. At present, it is uncertain whether this approach would even be legal (the European Commission is investigating), and in practice, no third country is willing to host a "regional disembarkation platform", which makes it unlikely that much will come of this idea soon.

Aside from this distraction, the current proposals for Dublin reform suffer from a serious flaw: While they would strengthen the EU's role in rule-making, they leave member states, rather than 
the EU itself, primarily responsible for implementation and financing. The new rules would more firmly establish which EU member state is responsible for a given asylum seeker; they would also harmonise reception conditions and asylum procedures. However, some member states would inevitably remain more attractive destinations than others. With open borders in the Schengen area, each member state would continue to face strong incentives to minimise the number of asylum applicants by making itself less attractive than other member states - raising the spectre of a race to the bottom in reception conditions. Furthermore, the current proposals would relocate asylum applicants from member states of first arrival only if the latter are severely overstretched and the applicants are very likely to receive protection in the EU, given their nationality. However, among those asylum seekers who arrive in Italy via the Central Mediterranean migration route, only a minority ever receive protected status. Therefore, the current proposals would do little to help Italy deal with the large number of asylum seekers that it has historically received.

To address these shortcomings, it is crucial to recognise that the protection of refugees through a well-working asylum system constitutes a public good at the EU level. Hence, the theory of fiscal federalism (multi-level economic governance) suggests that the asylum system should be governed and financed by the EU. On the ground, staff from the EU and member states would collaborate to operate the system. Financing from the EU budget would ensure that all member states contribute according to their ability to pay, acting in solidarity. At the same time, member states that are especially affected by the inflow of asylum seekers would experience some relief.

The asylum-related tasks that may be centralised include the reception, registration and hosting of asylum seekers close to the point of first entry into the EU, the asylum procedures themselves, and the return of rejected applicants. With fair and fast asylum procedures and EU financing, there would be no need to relocate asylum seekers to other member states. In most EU member states, the number of recognised refugees would probably remain manageable; any relocation could be voluntary in line with the concept of "flexible solidarity". An asylum system operated and financed by the EU would involve major changes in EU and member state institutions and would take some time to implement. One possible intermediate step would be for the EU to provide substantially more financial, administrative and logistical support to member states that receive a disproportionately large number of asylum applicants. In addition, the EU may assume more responsibility for returning rejected applicants to their countries of origin; there are clear economies of scale in negotiating and implementing effective agreements for return and readmission at the EU rather than at the member state level.

Finally, cooperation and dialogue are required not only among EU institutions and member states. Globally, most refugees are hosted by low- and middle-income countries that depend on international support to ensure that refugees can live with dignity. The EU and its member states already share in the responsibility for protecting these refugees by providing financial support through multilateral and bilateral channels. In doing so, they not only fulfil a humanitarian obligation, but also help to prevent secondary movements of refugees, including to the EU. This is a key element of managing irregular migration to the EU. Similarly, more opportunities for legal labour migration, especially from Africa to the EU, will be required to reduce irregular immigration. On the one hand, the EU needs the cooperation of countries of origin to return rejected asylum applicants (being able to do so is essential for the functioning of the asylum system). On the other hand, governments in countries of origin risk becoming unpopular with their voters if they are seen as cooperating with enforced returns of their citizens. Legal migration opportunities would be popular with voters and could be made conditional on effective readmission, offering a way out of this dilemma.

Matthias Lücke, The Kiel Institute for the World Economy, Germany; and Mercator Dialogue on Asylum and Migration (MEDAM), Kiel, Germany.
1 Mercator Dialogue on Asylum and Migration in Europe (MEDAM): 2018 MEDAM Assessment Report on Asylum and Migration Policies in Europe. Flexible Solidarity: A comprehensive strategy for asylum and immigration in the EU, available at http://www.medam-migration.eu/en/archive/publications/2018-medam-assessment-report-on-asylum-and-migration-policies-in-europe-2. 